\title{
Kształtowanie środowiska miejskiego na przykładzie wielofunkcyjnych zespołów o wiodącej funkcji biurowej
}

\section{The urban environment creation - multifunctional business districts example}

\begin{abstract}
Streszczenie
Brak wystarczających środków finansowych sektora publicznego na pokrycie kosztów, w tym zarówno na przygotowanie, jak i realizację niektórych zadań miejskich w miastach Europy Zachodniej, przyczyniło się do poszukiwania nowych rozwiązań. Przedsięwzięcia takie realizowane są najczęściej na zasadzie współdziałania podmiotów publicznych, działających w ramach inwestycji celu publicznego oraz prywatnych inwestorów, promotorów, przedsiębiorstw. Proces realizacji wielofunkcyjnych zespołów biurowych, powstałych w ostatnich pięćdziesięciu latach, pokazuje złożone procesy realizacji i koordynacji działań związanych z kształtowaniem środowiska miejskiego. W artykule przybliżono go na podstawie szczegółowej analizy wielofunkcyjnego zespołu biurowego Potsdamer Platz.
\end{abstract}

Słowa kluczowe: środowisko miejskie, funkcja biurowa, proces realizacji

\begin{abstract}
The lack of sufficient public sector financial resources to cover the costs in Western European cities, including the preparation and implementation of some of the city tasks contributed searching new solutions. Such projects are usually carried out on the basis of cooperation between public entities operating within the framework of public and private investors, promoters, businesses etc. The process of implementing multifunctional office complexes has shown the complex processes of implementing and coordinating the activities related to shaping the urban environment in the last fifty years. The process of shaping and realization of the office complex is illustrated in the example of the multi-purpose Potsdamer Platz.
\end{abstract}

Keywords: urban environment, office function, process of developing 


\section{WSTĘP}

Współczesna, wyspecjalizowana praca biurowa polega na szeroko rozumianych działaniach informacyjno-decyzyjnych, czyli pozyskiwaniu wiedzy potrzebnej do podejmowania racjonalnych decyzji. Możliwość natychmiastowego przekazu zarówno informacji, jak i decyzji w skali całego globu sprzyja rozwojowi wyspecjalizowanych ośrodków zarządzania we wszystkich dziedzinach światowej gospodarki, funkcjonujących w odległych od siebie miejscach. Wybór lokalizacji agend i przedstawicielstw znaczących firm i korporacji, oprócz nadrzędnego czynnika ekonomicznego, w tym dostępu do wysoko wykwalifikowanej rzeszy pracowników i niższych kosztów pracy, zależy od szeroko rozumianej atrakcyjności lokalizacji.

Zmiana charakteru pracy, a zarazem kwalifikacji pracowników epoki informacyjnej (poprzemysłowej), w porównaniu z pracownikami epoki przemysłowej, wpływa na inny tryb życia. Wysoko wykwalifikowani pracownicy biurowi, często bardzo dobrze uposażeni, oczekują wysokiej jakości życia. Wymagania dotyczą odpowiednich warunków zamieszkania, atrakcyjnych warunków wypoczynku i możliwości korzystania z zróżnicowanej oferty usług, a także komfortowych warunków pracy.

Komponowanie zespołów biurowych, także wielofunkcyjnych, daje możliwość kształtowania przestrzeni miejskiej. Na przestrzeni ostatnich kilkudziesięciu lat w wyniku zmieniających się koncepcji i poglądów można wyróżnić kilka sposobów kształtowania i rozmieszczenia obiektów biurowych.

\section{EWOLUCJA STRUKTUR BIUROWYCH W PRZESTRZENI MIASTA}

W pierwszej kolejności firmy i przedsiębiorstwa adaptują kamienice zlokalizowane w obszarze śródmiejskim. Korzystna lokalizacja umożliwiała dobrą dostępność komunikacyjną, gwarantowała różnorodność usług oraz wpływała na wizerunek firmy. Obiekty początkowo przybierają formę płaskich brył, by stopniowo zwiększyć swoją wysokość. Forma pozbawiona detali, anonimowa, abstrakcyjna w dużej mierze wynikała ze względów reprezentacyjnych oraz z systemu organizacji pracy - układy celkowe dwu-, trzytraktowe, następnie wieloosiowe. Obiekty biurowe, lokalizowane przede wszystkim w centrach miast, niejednokrotnie wyższe od obiektów mieszkalnych i handlowych, zaczęły dominować w sylwetach miast. Swoją wielkością oraz oddziaływaniem na otaczającą je tkankę zaczęły zaburzać dotychczasową strukturę.

Kolejny etap w ewolucji struktur biurowych to okres deglomeracji biur poza śródmieście. Zmiana dotychczasowego podejścia do lokalizacji biur spowodowana była falą krytyki i protestów różnorodnych środowisk. Intensywne nasycanie stref śródmiejskich funkcją biurową spowodowało naruszenie oryginalnej tkanki miejskiej, wyludnianie śródmieść, chaos przestrzenny i funkcjonalny. W założeniach przyjęto, że nastąpi decentralizacja funkcji biurowych. Tworzone 
są także małe założenia urbanistyczne. Najczęściej zespoły lokalizowane były z jednostkami naukowo-technicznymi w przestrzeni zielonej z wygodnym dojazdem. Kształt obiektów lokalizowanych poza centrami miast przybierał postać zwartych i płaskich budynków, zazwyczaj 5-8-kondygnacyjnych o głębokich traktach. Rozwój oraz wzrost znaczenia aspektów społecznych, socjalnych, ekologicznych oraz humanizacja pracy wpływa na ukształtowanie przestrzeni związanych z pracą biurową. Inwestorzy oraz projektanci dążą do indywidualnych opracowań, z podkreśleniem integracji z naturą i przyrodą. Zazwyczaj budynki biurowe są rozczłonkowanymi niskimi obiektami formowanymi horyzontalnie. Z końcem XX wieku nadal widoczny jest duży nacisk inwestorów na umieszczanie administracji w strefach śródmiejskich miast. W celu ochrony śródmieść podejmowane są różnorodne działania zmierzające do ograniczenia dynamicznego i żywiołowego rozrostu funkcji biurowych. Działania ukierunkowane są na wyznaczanie terenów, gdzie można w sposób nieskrępowany wznosić obiekty administracyjne, a obszar, na którym się znajdą, będzie dobrze skomunikowany ze śródmieściem. Na przykład tworzenie dzielnicy o wiodącej funkcji biurowej La Défense w Paryżu albo przebudowa terenów zdegradowanych, poprzemysłowych w kierunku wielofunkcyjnych zespołów z przewagą funkcji biurowej, np. przebudowa byłych doków portowych w Londynie lub przebudowa zdegradowanych terenów w rejonie Potsdamer Platz w Berlinie, jak też tworzenie „parków biurowych”, gdzie strefa pracy współistnieje z terenami rekreacyjnymi.

\section{ZNACZENIE FUNKCJI BIUROWEJ}

Rozwój funkcji biurowych wpłynął na przeobrażenie struktury miast. Zagadnienie to dotyczy przeważnie dużych miast, zwłaszcza europejskich stolic. Obserwując przesunięcia w sektorach zatrudnienia, można stwierdzić, że biura zajęły miejsce przemysłu, stając się głównymi miejscami pracy (oprócz usług) w rozwiniętych gospodarczo krajach. Znaczenie funkcjonalne obiektów biurowych wynika z kilku czynników.

W relacjach z elementami struktury miejskiej funkcja biurowa w stosunku do otoczenia jest funkcją nieuciążliwą. Wytwarzany produkt jest produktem wirtualnym, niewymagającym fizycznego transportu surowców i produktów. Funkcja biurowa, sama w sobie nie stanowiąca uciążliwości, może być łączona z innymi funkcjami - usługami, mieszkalnictwem, rekreacją itd. Biura gromadzą dużą liczbę pracowników w konkretnym obszarze miasta. Dojazd i wyjazd z miejsca pracy skutkuje wzmożonym ruchem kołowo-pieszym interesantów. Intensywność oraz nasilenie jest różne w określonych porach. Wpływ na natężenie i nasycenie stref mają także interesanci firm związanych z pracą biurową, powodując czasowe nasilenie ruchu pieszo-kołowego. W zależności od wykonywanego rodzaju pracy biurowej i świadczonych usług liczba i nasilenie interesantów jest zmienna. Największe natężenie zauważalne jest o dwóch porach: rano i po południu. Związane jest to bezpośrednio z dotarciem pracownika biura do pracy i z jego powrotem do miejsca zamieszkania. 
Rozwiązania przestrzenne obiektów biurowych uzależnione są od lokalizacji i uwarunkowań, jakim podlegają budynki w danym miejscu, np. ograniczeniom przestrzennym (wysokość, kubatura) czy ekonomicznym (wysokiej cenie gruntów). Wysokość i kubatura obiektów biurowych uzależniona jest od obowiązujących aktów prawnych (różnych w zależności od kraju), obejmujących przestrzeń miasta, oraz prowadzonej polityki przestrzennej. Na formę budynków ma także wpływ rozwój techniki i nowoczesnych technologii.

Funkcja biurowa może być wyróżnikiem w panoramie i sylwecie miasta. Swoja formą, w kontekście już istniejących zespołów lub obiektów wysokich (zwłaszcza dotyczy to miast historycznych), może ją wzmocnić i podkreślić przez świadome jej komponowanie. Sytuacja może także być zgoła odmienna, kiedy może nastąpić degradacja panoramy i sylwety miasta. Może to nastąpić przez zasłonięcie najbardziej charakterystycznych obiektów panoramy lub stworzenie nowego tła, często burzącego wizualny odbiór. Obiekty biurowe mogą przyjmować różne formy w różnych obszarach miasta i pomimo interesującej architektury mogą wprowadzić dysonans w tkance miasta. Często, dominując nad funkcją mieszkalną i usługową, zmieniają kompozycję oraz wygląd panoramy miasta. Sytuacja taka spowodowana jest brakiem kontroli nad rozrostem funkcji biurowych lub świadomie prowadzonej łagodnej polityki przestrzennej. Świadomość władz i dostrzeganie roli funkcji biurowych we współczesnym rozwoju ekonomicznym może być nastawione na zyski i wzrost ekonomiczny miasta, skutkując nieodwracalnymi zmianami w przestrzeni. Taką sytuację możemy zauważyć np. we Frankfurcie nad Menem. Rozmieszczone w sposób dosyć przypadkowy obiekty biurowe, często o wartościowej architekturze, nie są związane funkcjonalnie i kompozycyjnie z otoczeniem.

\section{KOORDYNACJA DZIAŁAŃ ZWIAZZANYCH Z REALIZACJĄ FUNKCJI BIUROWYCH}

Funkcje biurowe są w sposób różnorodny lokalizowane w przestrzeni miast. Różne podejście władz oraz społeczeństwa, w zależności od odmiennych kryteriów ekonomicznych, rozwoju społecznego i kulturalnego, stanu gospodarki, kręgu kulturowego czy wreszcie różnorodnej hierarchii wartości w stosunku do przestrzeni miast, jest także uzależnione od prowadzonej polityki przestrzennej w stosunku do funkcji biurowych.

W wielu europejskich miastach działania związane z koordynowaniem rozwoju i lokalizacją funkcji biurowych odbywać się może na różnych poziomach: lokalnym, regionalnym, centralnym. Koordynacja działań związanych z realizacją funkcji biurowych odbywa się na trzech poziomach opracowań planistycznych. Pierwszym opracowaniem jest strategia rozwoju miasta, w której określone zostają podstawowe kierunki rozwoju zespołu miejskiego oraz określona zostaje wizja miasta. Kolejny - drugi poziom opracowań planistycznych obejmuje kierunkowe plany zagospodarowania, w których określone zostają zasady polityki przestrzennej. Trzeci etap koordynacji, obejmujący określenie przeznaczenia i możliwości 
przekształcenia danego obszaru, zapisane jest w miejscowych planach zagospodarowania przestrzennego. Na tym etapie następuje uszczegółowienie realizacji, opracowanie planów, projektów realizacyjnych i określenie działań. Realizacja założeń polityki dotyczącej lokalizacji funkcji biurowej związana jest także z wprowadzaniem zachęt, jak i ograniczeń względem inwestorów. Zastosowane mogą być zachęty w zakresie administracyjno-podatkowym, jak również mogą zostać wprowadzone ograniczenia lub możliwości funkcjonalno-przestrzenne. Stosowane są uproszczone procedury związane z uzyskaniem zgody na realizację budynków biurowych, tworzone są tzw. strefy rozwoju, parki technologiczne. Tworzone są korzystne warunki dla inwestorów przez ustanowienie tzw. specjalnej strefy ekonomicznej (np. Enterprise Zone podczas budowy londyńskich doków). Natomiast ograniczenia polegają na wprowadzeniu dodatkowych opłat od wznoszenia budynków w niepożądanych strefach. Stosowanie zachęt do lokalizowania w konkretnie wyznaczonych miejscach obejmuje także działania przestrzenne, np. tworzenie korzystnych warunków infrastrukturalnych, rozwiązań komunikacyjnych. Ważną rolę w kształtowaniu struktury miasta ma także elastyczne lub restrykcyjne podejście w stosunku do samej formy przestrzennej obiektu lub zespołu obiektów. Przeprowadzane są studia związane z oddziaływaniem budynków wysokich (w tym biurowych) na strukturę miasta. Ze względu na walory historyczne i kulturowe miast na poziomie zapisów planu zagospodarowania określa się współczynnik intensywności zabudowy, wprowadza ograniczenia dotyczące stref lokalizacji oraz ograniczeń względem kubatury, gabarytów, wysokości.

W procesie przekształcania struktury miejskiej szczególnie ważny jest proces przygotowania projektów urbanistycznych. Utworzenie szczegółowych projektów daje możliwość uniknięcia niepożądanych efektów gry rynkowej, a także możliwość osiągnięcia zamierzonych rozwiązań przestrzennych. Dodatkowo działania te są poprzedzone konkursami urbanistyczno-architektonicznymi, a wybrane koncepcje dają podstawę do opracowania projektów realizacyjnych.

\section{ANALIZA ZESPOŁU POTSDAMER PLATZ}

Wśród wielu przykładów operacji urbanistycznych z udziałem funkcji biurowych znacząca rolę odgrywa zespół Potsdamer Platz w rejonie Bramy Brandenburskiej, będący wielofunkcyjnym publiczno-prywatnym założeniem, powstałym po przebudowie zdegradowanych terenów po zburzeniu muru berlińskiego. Pierwszy etap działań obejmował zorganizowanie ideowego konkursu urbanistycznego. Koncepcja zabudowy, zaproponowana przez Heinza Hilmera i Christopha Sattlera, stała się podstawą do przygotowania planu zabudowy, zatwierdzonego przez organ wykonawczy jako podstawa do dalszych działań budowlanych. Kolejny etap dotyczył ogłoszenia konkursu na projekt realizacyjny podlegający wytycznym określonym w koncepcji planu zabudowania. Ustanowiono mniejsze zadania projektowe, 
do których zaproszono innych uczestników. Dzięki współpracy jednostek określono założenia i przygotowano zasady projektowania. Po roku prac studialno-koncepcyjnych ukończono plan realizacyjny i określono zasady projektowania.

Cechą charakterystyczną zaproponowanego układu zabudowy są wnętrza urbanistyczne o sprecyzowanej formie, nawiązujące do tradycyjnego sposobu budowania miast w układzie ulic i placów (il. 1).

Plan realizacyjny, przygotowany przez zespół Renzo Piano i Christopha Kohlbeckera, utrzymał charakter zabudowy zgodnie z wytycznymi określonymi w planach regulacyjnych. Rozwiązanie przestrzeni publicznych wpłynęło na całościową i kompleksową rewitalizację zdegradowanego terenu. Jednoznacznie sprecyzowane przestrzenie publiczne i prywatne zostały odtworzone, powstała sieć ulic w oparciu o historyczny układ sprzed 1945 roku. Zwarta ośmio- i dziewięciokondygnacyjna zabudowa wyznaczyła ulice (Potsdamer, Bellevue, Link, Eichhorn, Schelling) i place (plac Poczdamski, Lipski, Marleny Dietrich). W celu zaznaczenia zespołu w skali miasta i otoczenia zaprojektowano kilka wysokich budynków, które dominując w układzie, nabierają znaczenia kompozycyjnego ${ }^{1}$. Wysokie obiekty sprawiają wrażenie bramy wprowadzającej do zespołu, akcentują narożnik placu Poczdamskiego i wskazują historyczny początek drogi z Berlina do Poczdamu w skali miasta. Wieżowiec projektu Renzo Piano, usytuowany przy kanale Landwehry, domyka założenie od południa oraz staje się zamknięciem widokowym ulic. Układ został wzbogacony o dodatkowe przejścia i dzieli zabudowę na poszczególne bloki². Nieograniczony dostęp do parterów wszystkich budynków jest jednym z najważniejszych elementów koncepcji harmonijnego współistnienia przestrzeni publicznych i prywatnych na Potsdamer Platz. Ważnymi miejscami dla całości założenia są place: Marleny Dietrich oraz Sony Center. Oba stanowią miejsce spotkań i punkty centralne. Zespół realizuje także zasadę rozdzielenia strefy pieszej i kołowej (dostępność zapewnia metro, strefa parkingów pod założeniem).

Plac Marleny Dietrich w rzucie ma kształt nieregularnego wieloboku. Nieregularność ta wynikła z układu osi ulic dochodzących do placu (il. 2). Sama konstrukcja placu - układ budynków, przeszklone, a zarazem współgrające kolorystycznie elewacje, zróżnicowana wysokościowo posadzka - sprawia wrażenie zarówno sceny, jak i widowni. Podobny efekt osiągnięto w centrum układu Sony Center (il. 3). Skala założenia i układ obiektów sprawia wrażenie dziedzińca, a zarazem placu miejskiego. Budynki otaczają owalne forum, na którym rozgrywa się spektakl życia miasta. Szczególnie interesującym elementem architektonicznym jest konstrukcja zadaszenia. Podobna do namiotu, owalna, ażurowa struktura, podwieszona nad wewnętrznym dziedzińcem kompleksu, nocą jest podświetlana tęczą kolorów. Dynamiczna konstrukcja, wpływająca na ciągłą zmianę w wyglądzie placu, wywołuje imponującą grę cieni, kolorów i nastrojów.

Omawiając problematykę kompozycji zespołów biurowych, należy zwrócić uwagę, w jaki sposób Potsdamer Platz jest postrzegany przez widzów, przechodniów, użytkowników.

W koncepcji zespołu świadomie zastosowano różnorodne elementy kompozycji przestrzennej. Została umiejętnie wykorzystana teoria postrzegania obiektów i zespołów z pozornym 
skracaniem odległości, określeniem punktów widokowych, martwych pól. W sposób bardzo czytelny elementy struktury przestrzennej oddziałują na obserwatora. Powiązano pod względem widokowym nowo projektowany zespół z istniejącymi zespołami zabudowy i ulicami, wzbogacając perspektywę ulic i podnosząc w ten sposób atrakcyjność widokową. Osiągnięto to, domykając istniejące ulice wysokimi obiektami biurowymi przy Potsdamer Platz oraz przy Schellingstrasse. Zostały stworzone układy z zamierzoną sekwencją wnętrz oraz zastosowano strefy graniczne z atrakcyjnymi widokami. Ulice, oparte na zasadzie budowy tradycyjnej ulicy, w proporcjach dostosowane do skali człowieka, wprowadzają do obszernych placów o zróżnicowanej architekturze, wywołując wrażenie dużego kontrastu skali, natężenia światła, przestronności i wielkości wnętrza. Rzeźby, zieleń niska i wysoka, mała architektura, zaakcentowanie narożników jednoznacznie określają przestrzeń, w której znajduje się obserwator, i wzbogacają kompozycję. Poszczególne place i ulice stwarzają wrażenie indywidualnych, ale zintegrowanych. Nie powodują dezorientacji. Wprowadzone elementy takie jak linie i płaszczyzny, kierujące oraz zamykające wzrok (stopnie, rampy, cieki wodne, zróżnicowana posadzka pod względem kolorystki i użytego materiału), elementy pionowe w postaci akcentów - rzeźb czy zieleni, a także barwa elementów detalu urbanistycznego i zróżnicowane światło (dzienne i sztuczne) dopełniają kompozycyjnie całe założenie. Płaszczyzny wodne, ujęte w geometryczne formy, wnoszą nową jakość w przestrzeń publiczną (il. 4), będąc nie tylko dopełnieniem wnętrza urbanistycznego i wartością estetyczną, ale przez zintegrowanie z systemem retencji wody deszczowej podnosząc walory ekologiczne przestrzeni miejskich.

Analizując przytoczony przykład pod względem kompozycyjnym, można stwierdzić, że założenie zostało zaprojektowane tak, by obiekty tworzyły różnorodne wnętrza urbanistyczne, ale było spójne kompozycyjnie i przestrzennie. Stworzone ciągi czasoprzestrzenne - trasy uliczne, place - dostarczają zmiennych wrażeń, dzięki czemu przestrzeń wydaje się atrakcyjna i ciekawa. Dominanty wskazują najważniejsze punkty założenia. Odczytywane jako „bramy” wskazują miejsca graniczne, a zarazem tworzą zamknięcia widokowe ulic w szerokim kontekście urbanistycznym. Otwarcia wnętrz wypełnione są interesującymi i przyciągającymi wzrok widokami.

\section{ORGANIZACJA PROCESU TWORZENIA ZESPOŁÓW BIUROWYCH - UDZIAt RÓŻNYCH PODMIOTÓW}

Osiągnięcie maksymalnych efektów przestrzennych, ekonomicznych i społecznych jest trudnym przedsięwzięciem, wymaga bowiem skoordynowania skomplikowanych i wielokierunkowych działań. Znaczącą rolę w organizacji procesu tworzenia zespołów biurowych mają powoływane w tym celu specjalne jednostki koordynujące, zespoły specjalistów, których zadaniem jest przeprowadzenie zarówno od strony prawnej, finansowej, jak i przestrzennej i technicznej całego przedsięwzięcia. W różnych krajach proces ten różnie przebiega, jednakże zazwyczaj jest powoływana odpowiednia spółka, której zadaniem jest np. zakup i scalenie 
ziemi, precyzyjne zdefiniowanie projektu architektoniczno-urbanistycznego w partnerstwie z radą miasta i współpracującymi architektami, odpowiedzialność za prace związane z wykonaniem infrastruktury technicznej, sprzedaż ziemi deweloperom pod budowę obiektów prywatnych i publicznych, a także nadzór projektowy, w tym przeprowadzanie konkursów zagospodarowania terenów należących do prywatnych inwestorów. W przypadku Potsdamer Platz, terenu należącego do inwestorów prywatnych, powołano w biurze do spraw planowania specjalny referat. Jednostka ta ściśle współpracowała z przedstawicielem inwestora i czuwała nad procesem przygotowawczym i realizacją przedsięwzięcia.

Realizacja dużych programów tworzenia nowych centrów, a także przebudowania fragmentów miast ${ }^{3}$ obejmuje zróżnicowane, wielokierunkowe, zintegrowane działania, w ramach których zaangażowanych jest wiele podmiotów. Brak dostatecznych środków finansowych sektora publicznego na całkowite pokrycie kosztów przygotowania i realizacji konkretnych działań przyczyniło się do poszukiwania nowych rozwiązań. Rozwiązaniem takim stało się partnerstwo publiczno-prywatne. Przedsięwzięcia takie realizowane są najczęściej na zasadzie współdziałania podmiotów publicznych, działających w ramach inwestycji celu publicznego, oraz prywatnych inwestorów, promotorów, przedsiębiorstw, firm itd. Mogą dotyczyć szeregu rozwiązań formalnych, przestrzenno-funkcjonalnych, kompozycyjnych, ekonomicznych, społecznych, np. działań związanych z promowaniem inwestycji, przygotowania terenu pod przyszłe realizacje i inwestycje infrastrukturalne poprawiające jakość przestrzeni.

Obiekty biurowe mogą być wybudowane przez inwestora dla własnych potrzeb lub przez dewelopera i przeznaczone pod wynajem. Obszar problemowy w ramach działań na podstawie partnerstwa publiczno-prywatnego obejmuje zazwyczaj sektory transportowy, mieszkaniowy, kulturowy, rekreacyjny itd. W przypadku Potsdamer Platz właścicielem terenu były dwie międzynarodowe korporacje: Daimler-Chrysler i Sony, które oprócz budowy obiektów biurowych i mieszkalnych zaangażowały się w powstanie przestrzeni publicznych oraz funkcji kulturowych - miejskich placów z kinami, restauracjami, muzeum, teatrem i budynkiem handlowym.

\section{PODSUMOWANIE}

Przebudowa terenów śródmiejskich, proces realizacji wielofunkcyjnych zespołów biurowych są trudnymi, złożonymi i długotrwałymi procesami. Organizacja całego przedsięwzięcia możliwa jest wtedy, gdy mamy do czynienia ze świadomym koordynowaniem rozwoju wielofunkcyjnych zespołów. Począwszy od planowania strategicznego, przygotowania opracowań planistycznych i projektowych, popartych wieloma wieloaspektowymi studiami, konkursami, prowadzeniem zintegrowanej polityki miejskiej, a także współpracą z wieloma jednostkami, przedstawicielami inwestorów, lokalną społecznością oraz innymi uczestnikami procesu. Koordynowanie wielu elementów w długiej i wieloaspektowej drodze przygotowawczej może przynieść oczekiwane, korzystne dla miasta efekty funkcjonalno-przestrzenne. 


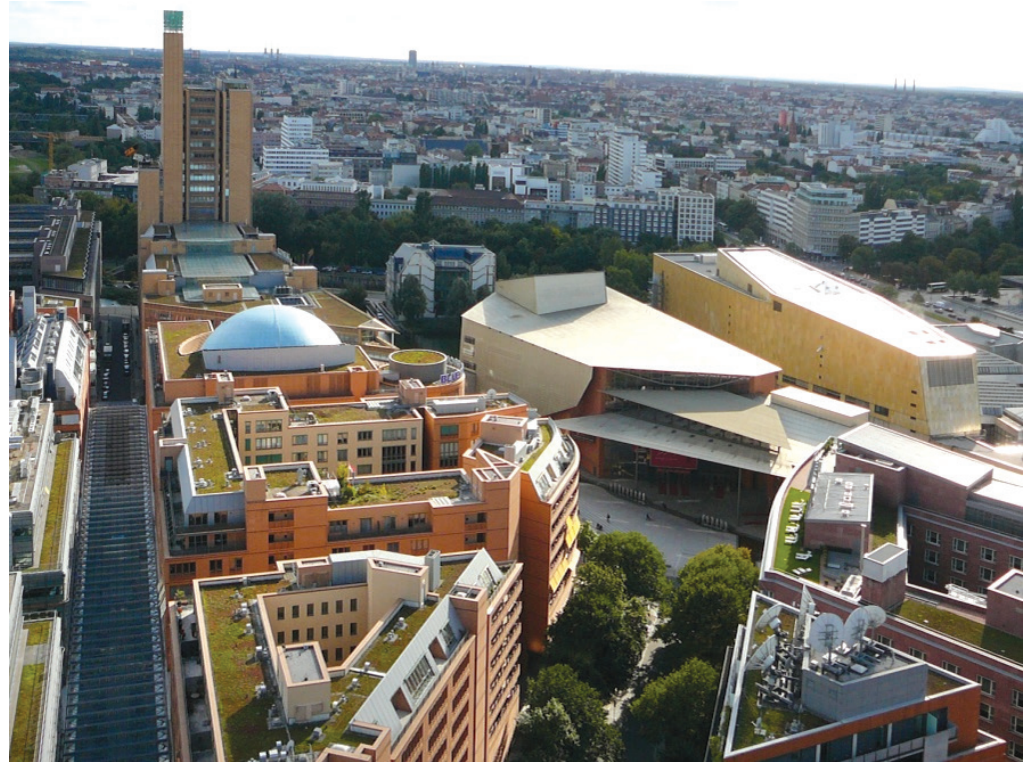

II. 1. Widok na Potsdamer oraz plac Marleny Dietrich (fot. Katarzyna Zawada-Pęgiel, 2008) III. 1. View of Potsdamer and Marlena Dietrich square

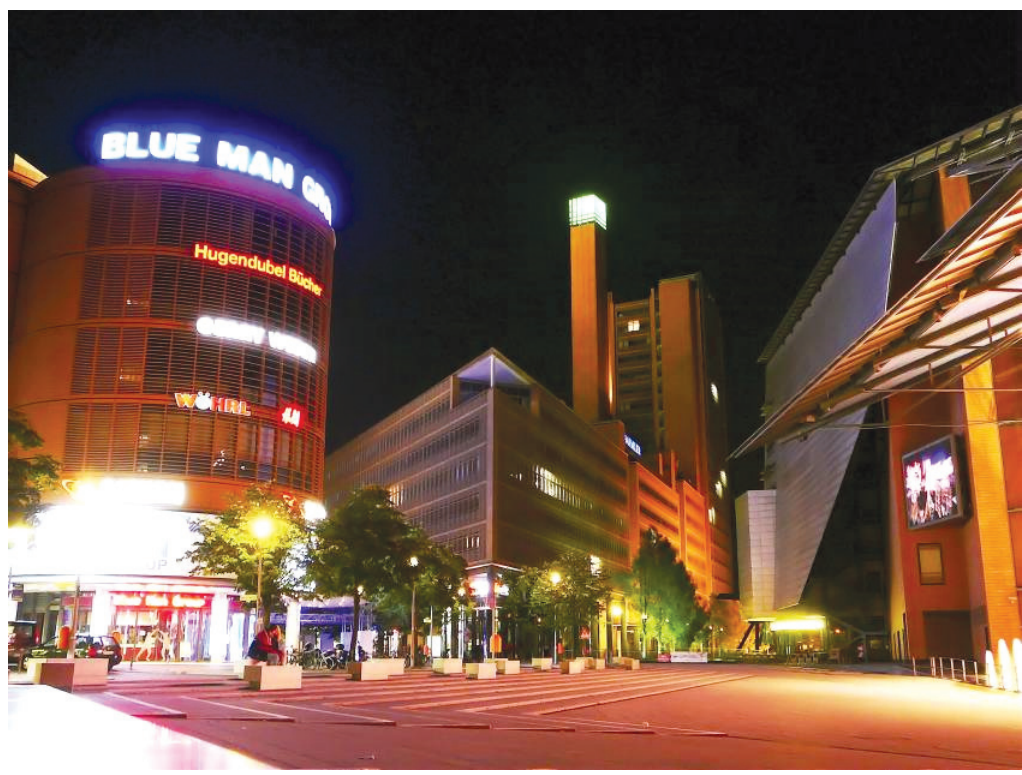

II. 2. Widok na plac Marleny Dietrich od strony założenia wodnego, zaprojektowany jako plac miejski (fot. Katarzyna Zawada-Pęgiel, 2010)

III. 2. View of Marlena Dietrich Square from the water founding site designed as a town square 


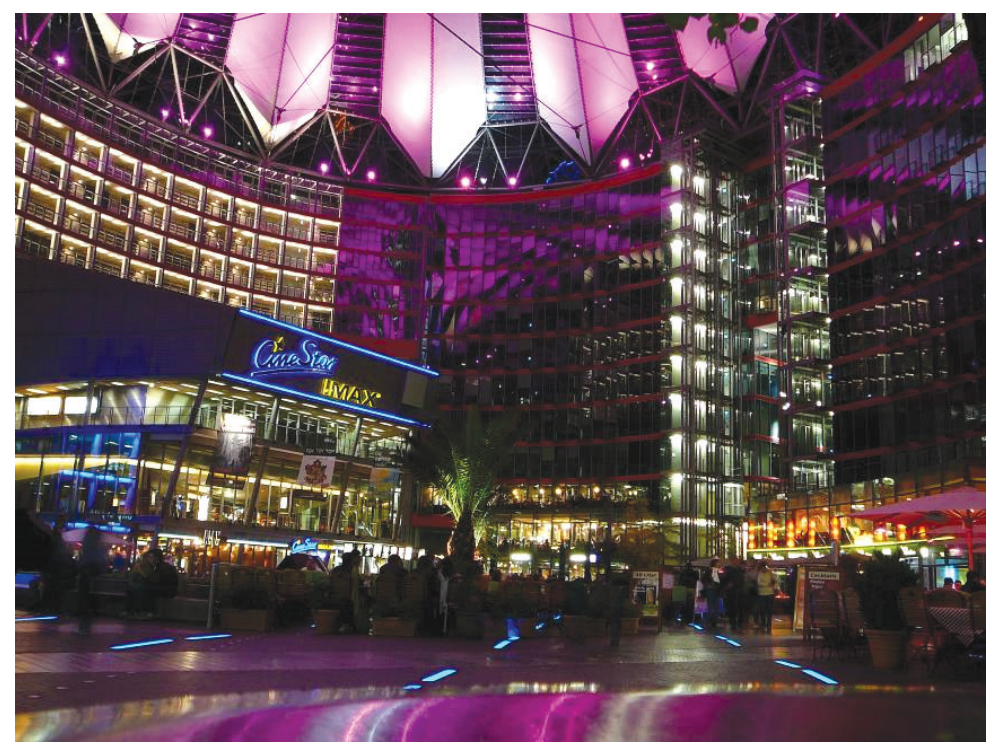

II. 3. Sony Center, plac, zaprojektowany jako miejsce spotkań i integracji pracowników i interesantów, przypomina zadaszone forum (fot. Katarzyna Zawada-Pęgiel, 2010)

III. 3. The Sony Center, a square designed as a meeting place for the integration of employees and visitors, resembles a covered forum

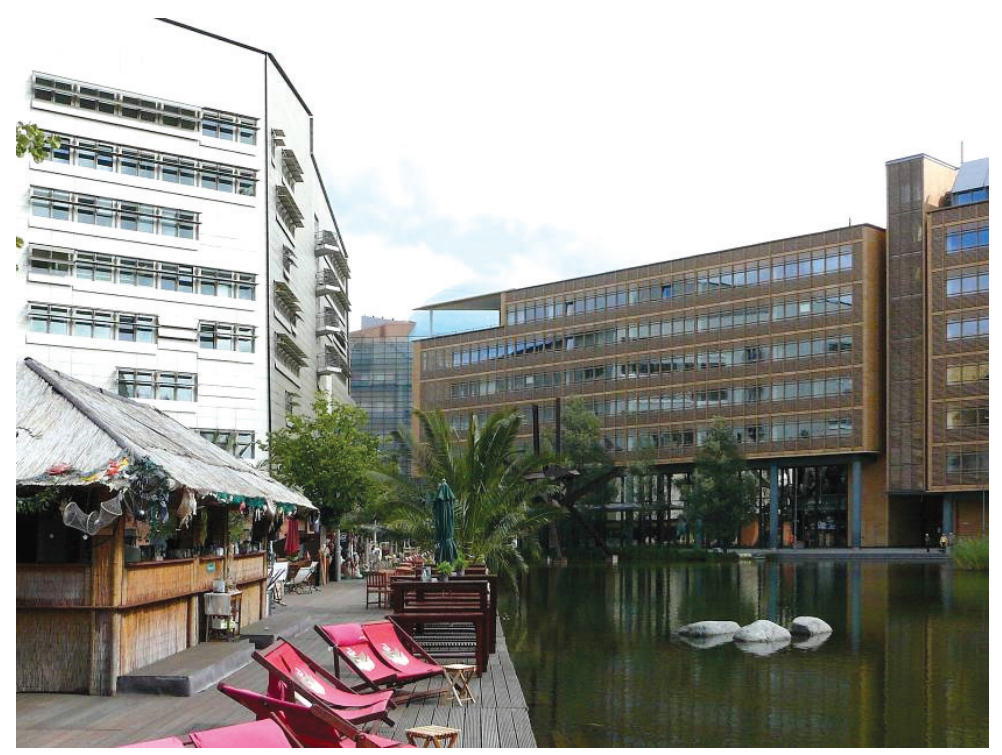

II. 4. Założenie wodne przy Marleny Dietrich (fot. Katarzyna Zawada-Pęgiel, 2010)

III. 4. The pond at the square at Marlene Dietrich 


\section{PRZYPISY}

1 Zespół dwóch wysokich biurowców (zachodni koniec ulicy Lipskiej), będących dominantami kompozycyjnymi, widoczny jest z wielu miejsc w Berlinie.

2 W przeważającej części zrealizowany zespół to układ zwartych kwartałów nowoczesnych budynków autorstwa znanych i cenionych architektów: R. Rogersa, U. Laubera i W. Wohra, J.R. Moneo, H. Kollhoffa, A Isozaki, O. Ungersa, H. Jahna.

3 W wielu przypadkach podejmowane działania są związane z przekształceniem terenów zdegradowanych, poprzemysłowych, znajdujących się na styku przedmieść i strefy śródmiejskiej, w kierunku wielofunkcyjnych zespołów miejskich o charakterze śródmiejskim, z dominującą funkcją biurowo-usługową. Np. realizacje przebudowy zdegradowanych terenów albo przebudowa terenów pokolejowych (rejon Paddington Station w Londynie) i terenów poportowych (Dockland w Londynie, Hafencity w Hamburgu), poprzemysłowych i innych.

\section{BIBLIOGRAFIA}

Brzozowska K., Partnerstwo publiczno-prywatne. Przesłanki, możliwości, bariery, CeDeWu, Warszawa 2006.

Gzell S., Projektowanie urbanistyczne jako jedno z narzędzi równoważenia rozwoju miast przykład placów Warszawy i Berlina, [w:] Trwały rozwój polskich miast nowym wyzwaniem dla planowania i zarządzania przestrzeniq, Heczko-Hyłowa E. (red.), Wydawnictwo Politechniki Krakowskiej, Kraków 2001, s. 133-156.

Jarzębowski W., Nowoczesne biuro. Organizacja i technika, PWE, Warszawa 1980.

Kopietz-Unger J., Urbanistyka w systemie planowania przestrzennego, Wydawnictwo Politechniki Poznańskiej, Poznań 2000.

Palej A., Miasta cywilizacji informacyjnej. Poszukiwanie równowagi pomiędzy światem fizycznym a światem wirtualnym, Wydawnictwo Politechniki Krakowskiej, Kraków 2003.

Pęski W., Zarzqdzanie zrównoważonym rozwojem miasta, Arkady, Warszawa 1999, s. 180-182.

Tytyk E., Aspekt innowacyjności w pracy biurowej, [w:] Ergonomia pracy biurowej, Złowodzki M., Pokorski J., Marek. T., Pietsch E. (red.), Kontekst, Kraków 2001.

Zawada-Pęgiel K., Wpływ rozwoju funkcji biurowych na przemianę struktury funkcjonalno-przestrzennej miast, ze szczególnym uwzględnieniem Krakowa, rozprawa doktorska, mps, 2013.

Złowodzki M., Technologiczne i środowiskowe projektowanie architektury biur, Wydawnictwo Politechniki Krakowskiej, Kraków 1997.

Pacholski L., Trzcieliński S., Borucki A., Sławińska M., Cztery czynniki przekształceń organizacji i zarządzania współczesnym biurem, [w:] Ergonomia pracy biurowej, Złowodzki M., Pokorski J., Marek. T., Pietsch E. (red.), Kontekst, Kraków 2001. 